\title{
IMPROVING THE SYSTEM OF MORTGAGE CREDITING OF RESIDENTIAL REAL ESTATE IN UKRAINE
}

\author{
Alexander GOLOVEN' ${ }^{1}$, Vladimir KORNEEV ${ }^{2}$, \\ Research Institute of Economics by Ministry of Economic Development and Trade of Ukraine, Ukraine
}

\begin{abstract}
The purpose of the article is to improve the system of mortgage crediting of residential real estate in Ukraine. Mortgage lending appeared in Ukraine in the early XVII century, today the actual problem is a small percentage of the banking book long-term mortgage loans, because banks, on the one hand, tend to rotate without the risk of short-term funds, another potential borrower of these loans, unfortunately, is not creditworthy. However, despite the risks, this banking product is a significant factor in the redistribution and accumulation of funds, the transformation of private savings into investment resources, the problem of housing, but also contributes to the stabilization of the economy in the country as a whole. Functioning and the distribution of mortgage capital, the possible financial risks, the interaction of the mortgage market by the financial, investment and monetary Affairs, leads to a certain complexity of the mechanism of functioning of the mortgage market of Ukraine in general. The relevance of this topic not only in the development of the housing market, but also the feasibility studies for the development of this issue. We present an analysis of the institutional environment of mortgage lending residential real estate, which gave an opportunity to identify and define the environment of modern residential real estate market, its relationship with other markets. Methodology. The survey is based on institutional structure of the mortgage market that has evolved independently of other structures, independently within country under the influence of specific socio-economic environment and economic policy. Results of the survey showed that mortgage lending can be providing the borrower with some free services, such as: long-term deposit on favorable terms, notary services, insurance, discounts on bank services, providing services to the bank and the developer, given appropriate training of the borrower and so forth. Practical implications. As practice shows, most need mortgage loans young and wealthy clients. With this purpose, you need also to diversify the types of loans. Young people without significant income, applying for social housing, while the wealthy - for luxury housing and placing home in a prestigious area of the city. Value/originality. Based on this survey bank mortgage lending should apply new forms and methods of mortgage lending, as well as implement the latest technology in the field of providing banking services and lending, especially mortgages not only in Ukraine, but in other developing countries.
\end{abstract}

Key words: banking, mortgage, lending, market, institution, residential real estate.

JEL Classification: G21, G29, G24

\section{Introduction}

At the moment in Ukraine quite intensively a system of effective regulation of mortgage lending is being formed. This is primarily due to the fact that quite a large number of the population lack adequate housing, and secondly, banks provide loans for housing, as better collateral than housing do not exist today. The implementation of the policy of mortgage lending, in turn, requires the creation of conditions for development of the property market and constant expansion of the sphere of housing. In this case, only the state is able to take on organizational, economic, financial and legal support for the mortgage market residential real estate.
The development of market relations in our country, the changing economic structure of society, especially in recent decades, that has guided both state and non-state legal institutions that can ensure effective functioning on the market. As evidenced by the experience of developed countries, the system of mortgage lending solves both economic and social problems. Therefore, the introduction of our country effective system of mortgage crediting of residential real estate contribute significantly to socio-economic stabilization of the economy.

To do this we first need to solve economic and legal problems in the field of mortgage, without which it is

Corresponding author:

${ }^{1}$ Department of Financial and Budget Policy, Research Institute of Economics by Ministry of Economic Development and Trade of Ukraine. E-mail: alexandr_goloven@ukr.net

${ }^{2}$ Department of Financial and Budget Policy, Research Institute of Economics by Ministry of Economic Development and Trade of Ukraine.

E-mail: vkorn27@list.ru 
impossible to establish the legal Institute of mortgage relevant content, which would ensure its effective implementation. However, the solution to these problems is very important and simple question, which is due not only to significant complexity of the mortgage relationship, but the ambiguity of their legal nature and many forms of application. The primary goal of state policy in the sphere of mortgage crediting of residential property must be consistent creation of institutional environment favorable for the development of national banking institutions and related organizations, their interaction with potential clients - borrowers, who need housing or its improvement.

\section{Improving the efficiency of mortgage lending}

Coming from the nature of mortgage lending, which underpins the development of the real estate market, mortgage lending is a multifaceted education, which, in addition to the large number of elements inherent in the complex relationship between the relevant components.

One of the key factors of improving the efficiency of mortgage lending as the basis for the development of the real estate market, as noted above, is the necessity of building efficient institutions in the existence and activity of which see the possibility of solving economic and social problems in Ukrainian society. To focus on solving this problem required the clarification and understanding of the role and place of the mortgage market in the national economy, identification of functional connections of the mortgage market with other elements of the economic system, clarifying the factors affecting changes in the system of development of residential properties and its activity. Obviously, compliance and reliability of such research to specific economic conditions is only possible with a clear understanding and definition of the institutional framework of mortgage lending residential real estate, especially in the context of post-crisis phenomena.

In the context of the issue of the institutional framework of mortgage lending, in our view, it is useful to consider two categories in the field of institutionalism as an economic doctrine based on the study of human relationships, institutions, governance, regulation and law and society. The first category is "the institution", the second "Institute". In the use of the terms "Institute" (lat. institutio, in French, English: institution) and "Institute" (lat. institutum, in French, English: institute) is manifest not only linguistically, but also essential content.

So, considering some of the Institute scientists in terms of customs, habits, informal systems, and the Institute - in the sense of the formalized incarnation and formalizing institutions. Some scientists under the Institute of any stable community of people to achieve a full and real expression of certain goal - state, family, party, Church, trade Union, etc. and institution - institution - the body of law covering a range of public institutions: educational institutions, research institutions, banking institutions, building organizations, etc.

By analysing the number of scientific publications, both domestic and foreign scientists (T. V. Gaidai, D. Frolova, S. Sorokina, A. V. Inshakov, V. N. Tarasevich, V. Hamilton and others, which considers the approach to the interpretation of the term "institution"), we can conclude that in the field of mortgage lending "institution" - it's the rules, that is, a mechanism, a process that due to the rules, regulations of mortgage lending and the institution is institutions, institutions, organizations and so on, which are the relevant levers of influence on the development of mortgage lending.

Some authors of the literature concerning the institutional structure of the mortgage market argue that it has evolved independently of other structures, i.e. independently within each country under the influence of specific socio-economic environment and economic policy. However, as a result of our studies and the aspect that mortgage lending has evolved as a result in General system of credit, and the findings of Russian scientists E. Chernich and O. Starkova, it can be argued that the institutional organization of the mortgage market was only later borrowed and further developed independently.

The justification for this assertion is based more on the fact that the institutional structure of the mortgage market has a number of common features of different areas of lending and solves almost the same problem on lending to various sectors of the national economy. Note that the institutes and established on the basis of their institutions are the result of coordination of interests of subjects of mortgage financial relations. This primarily contributes to the formation of the mortgage market, and secondly, creates a system of institutionalizing concerted economic interests of its subjects. This approach to the study of formation, operation and development of the mortgage market because the mortgage market is a complex conglomerate of economic relations and forms that are integrated into the framework of economic order, which is generated and is reproduced with the direct participation of economic actors and on the basis of their economic interests.

The negative side of development of institutes of mortgage lending is that the national banking system did not fully Finance the real sector, as observed in the advanced economies. In addition, domestic banking institutions are the main part of credits give for a short period, and banks with foreign capital not at risk to provide long-term loans for housing construction, and limited to short-term, thereby contributing to the outflow of resources from the real sector of the economy.

In our opinion, the state's adoption of respective normative and legislative acts on the establishment of related institutes in the field of mortgage lending, which has the above factors and exercise control over their task, reduce the cost of both the construction of housing, and areas of mortgage lending. The existence of such organizations stimulate the interaction of supply 
and demand in the housing market, uniting developers, banking institutions and the population, promote the implementation of effective mechanisms for recovery of the mortgage market.

\section{Institution environment of mortgage lending residential real estate}

Regulatory support in the processes of mortgage lending significantly affects the development of the property market, especially residential property, on which there is a constant demand and therefore should be effectively and vigorously developed the market of such proposal.

The analysis of the institutional environment of mortgage lending residential real estate has provided the opportunity to identify and define the environment of modern residential real estate market, its relationship with other markets (pic. 1.1).

As it's shown in pic. 1.1, it can be argued that the implementation of the priority directions in the sphere of housing construction and mortgage lending is impossible without a comprehensive restructuring of the institutional environment and improvement of the institutional structure of mortgage lending residential real estate. That is, it is necessary to form a reasonably balanced and effective institutional structure that will enable a transformation in the mortgage complex, which will be translated into mainstream market transformation of the entire economic system and all economic complex of Ukraine.

An important role in the field of mortgage lending to residential property occupied by public authorities and various state and non-state organizations and institutions, and in the sphere of ensuring of effective formation and development of the real estate market, the mortgage market infrastructure (pic. 1.2).

Institutional structure is both the result and the instrument by which the subjects of the mortgage market to realize their economic interests, and ultimately ensure effective functioning of the estate and the welfare of the population. And for the implementation of these tasks play an important role is mortgage-backed securities.

Successful and fundamentally new development of mortgage housing crediting in Ukraine will be impossible without the introduction and rapid development of institutional investors, which have become important suppliers of financial resources for the aforementioned market.

First of all we are talking about the introduction and the economic and social as well as political and organizational support to non-state and non-banking institutions: foundations, companies. Their role in the system of mortgage lending is very important, especially in the field of mortgage lending of housing construction.

It should be noted that in establishing these financial institutions, which would provide financial resources for the construction of housing, Ukraine significantly lags behind other countries. Today the crucial issues are the selection of appropriate these funds and establish a reliable system to manage which will ensure minimization of possible costs of the assets of these funds and ensure their growth.

In the current context of development of the national economy require a significant increase of the role of institutions such as mutual investment funds, insurance companies, credit unions, investment companies that should be particularly important investors of the mortgage housing market.

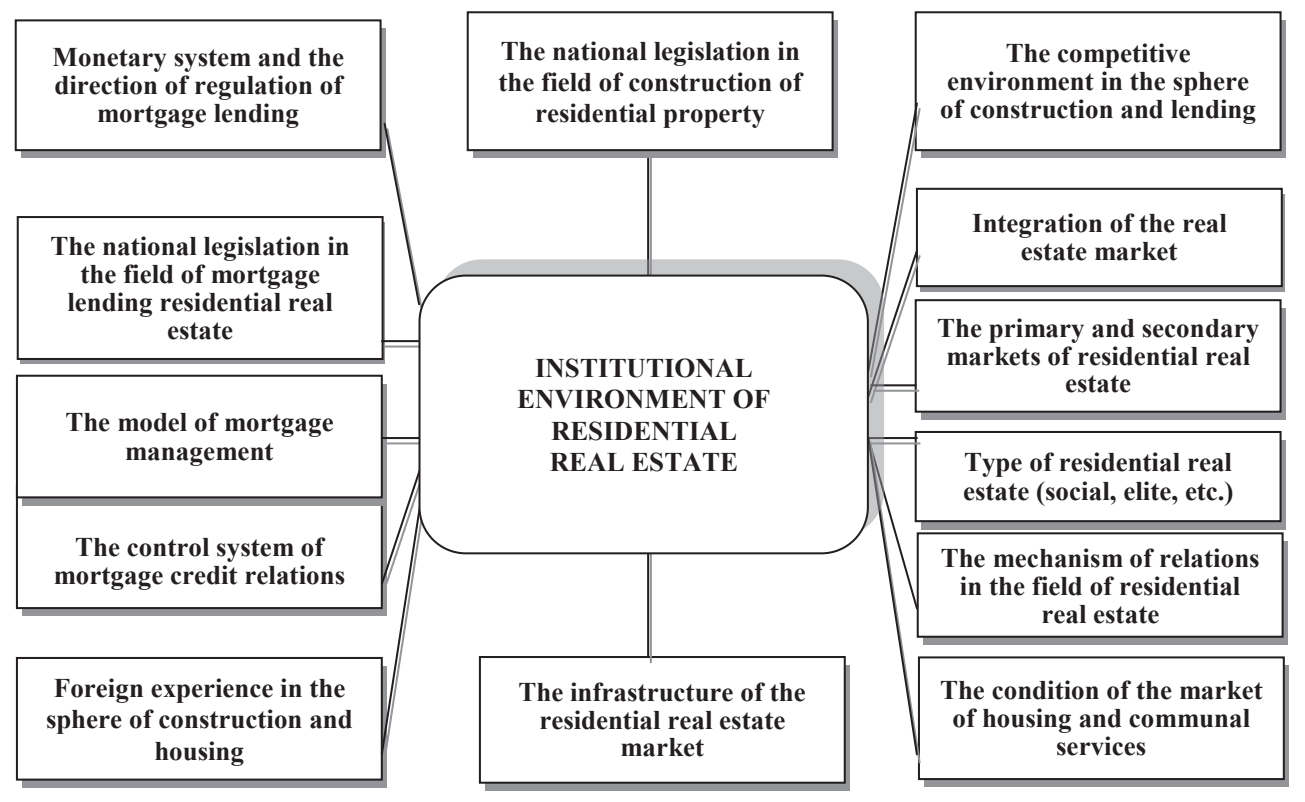

Pic. 1.1. The living conditions of mortgage of residential property

Note. Created by the author 
It should be noted that the activities of credit unions and cooperative banks in the mortgage market can be substantially strengthened through the establishment of effective legal framework for the expansion of cooperative housing mortgage loan.

In modern conditions there is a need in the formation and other financial-credit institutions of mortgage lending of housing. But, in our view, today focus on issues such as the creation of a highly developed and efficient institutional structure of mortgage lending market residential real estate.
A special role should be given with special banking institutions and credit agencies in the field of mortgage lending. In Ukraine to the bodies, carrying out regulation in the sphere of mortgage lending belongs to the national Commission on securities and stock market, State Commission for regulation of financial services markets of Ukraine, the national Bank of Ukraine, Ministry of Finance of Ukraine, State tax service of Ukraine and other bodies of state regulation, the state property Fund, State Committee of Ukraine for construction and architecture. As noted above,

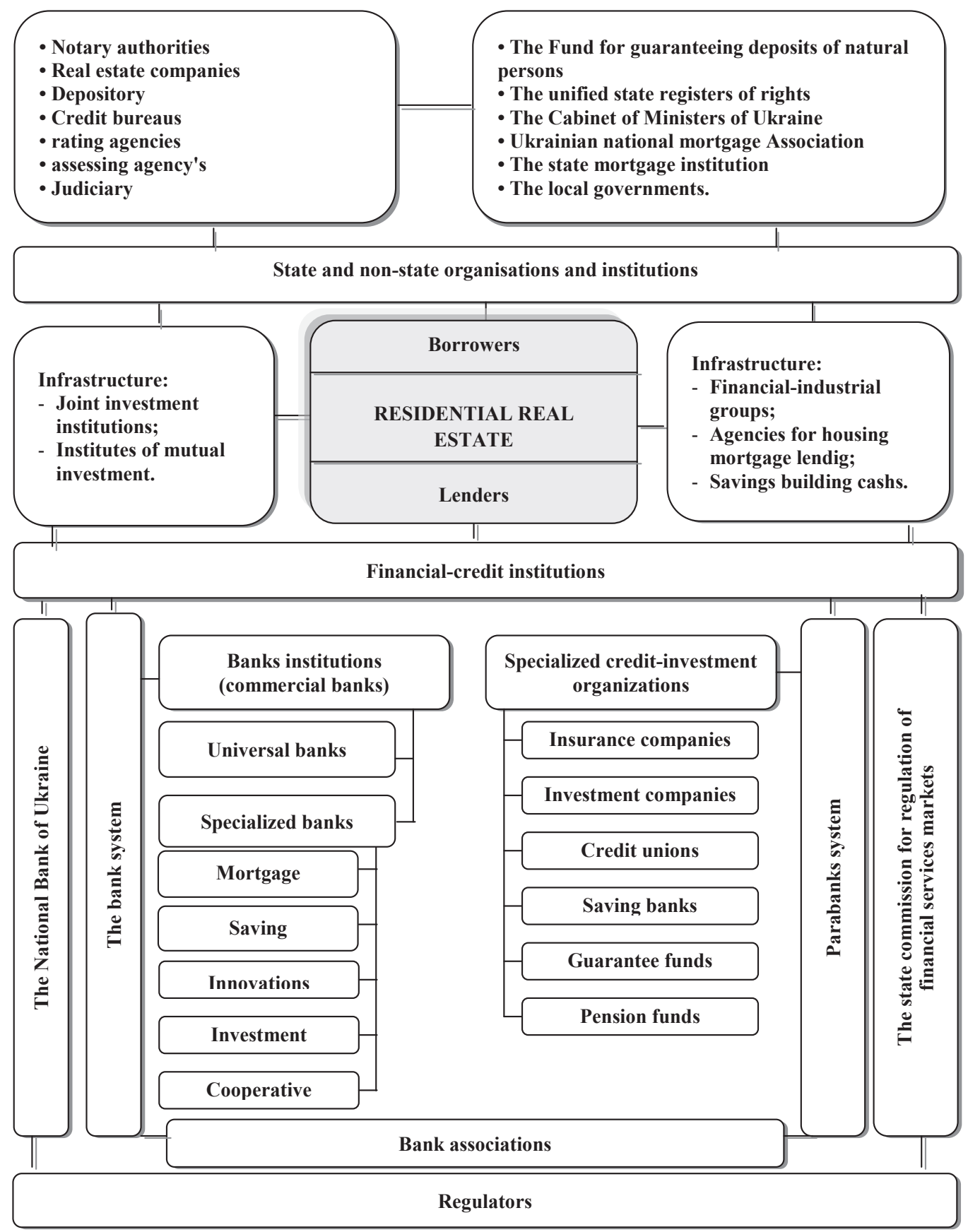

Pic. 1.2. The institutional structure of mortgage lending residential real estate

Note. Created by the author 
regulatory functions in the mortgage housing market are also held by the local authorities. It is important to note that the authorities who regulate the mortgage market, and include legislative authorities, Executive authorities at both the local and national levels.

Our proposed institutional structure of mortgage lending residential real estate should be an effective mechanism to relatively intensive housing development and lending.

It is worth to noting that on the state level to legislatively regulate issues related to the functioning of existing and creation of new institutions, which would take a direct part in the processes of mortgage lending. The most efficient system in the construction and real estate crediting is the Union of all the immediate participants of this process. This refers to the merging of structures that are associated with the construction, commissioning and real estate crediting, and also of local authorities who contributed to the construction of residential property, as well as monitored compliance with all regulations.

\section{Findings}

One commonin Ukraine directions ofinstitutionalization mortgage residential real estate market is the creation of institutions such as investment in construction companies. Example of a classic investment company is LCD "Kyivmiskbud", which was created in the late XX century. Housing company "Kyivmiskbud" unites as an effective and efficient mechanism to attract financial resources and an effective mechanism of investment and financing of construction and installation works, as well as to reduce the cost of development of infrastructure, manufacturing of construction materials, provision of transport and lifting means.

In our opinion, the establishment of associations institutions operating on the mortgage lending market, will significantly improve the quality, capacity, will reduce construction time, as between financial and industrial organizations of these institutions develop special relationships, which, as a rule, not peculiar to the economy as a whole. The peculiarity of these relations is that such organizations are not subject to the General laws of transformation of the economy that are directly manifest in the fact that credits for real sector of economy are more expensive than the profitability of production in the construction sector.

Development of associations of manufacturers, builders, financial and insurance companies in the system of housing construction will allow to solve some important problems of the industry of mortgage lending for mass housing that are associated with a particular transitional stage of socioeconomic development of Ukraine.

It should be noted that today there are many positive factors that significantly affect the development of mortgage lending, however, there are negative.

In turn, it's necessary minimize the negative factors, which significantly reduce the possibility of mortgage lending, and some to eliminate through the development of effective measures on creation of appropriate conditions, namely:

- reduce interest rates on mortgage loans;

- extend mortgage loans for construction and purchase of residential property up to 30 years;

- create a functioning institutional infrastructure which would include intermediary structures, such as realtors and insurance companies on a contractual basis with bank, which provided a customer search for mortgage lending and conducted insurance mortgage loans;

- improve the legislative and regulatory framework, which would explicitly regulate the mortgage lending market residential properties and contributed to the growth of the construction of a primary residence.

It should be noted that in the structure of organizationaleconomic mechanism of mortgage crediting of residential real estate important is the relationship between the Bank and the borrower and the bank and the developer, which

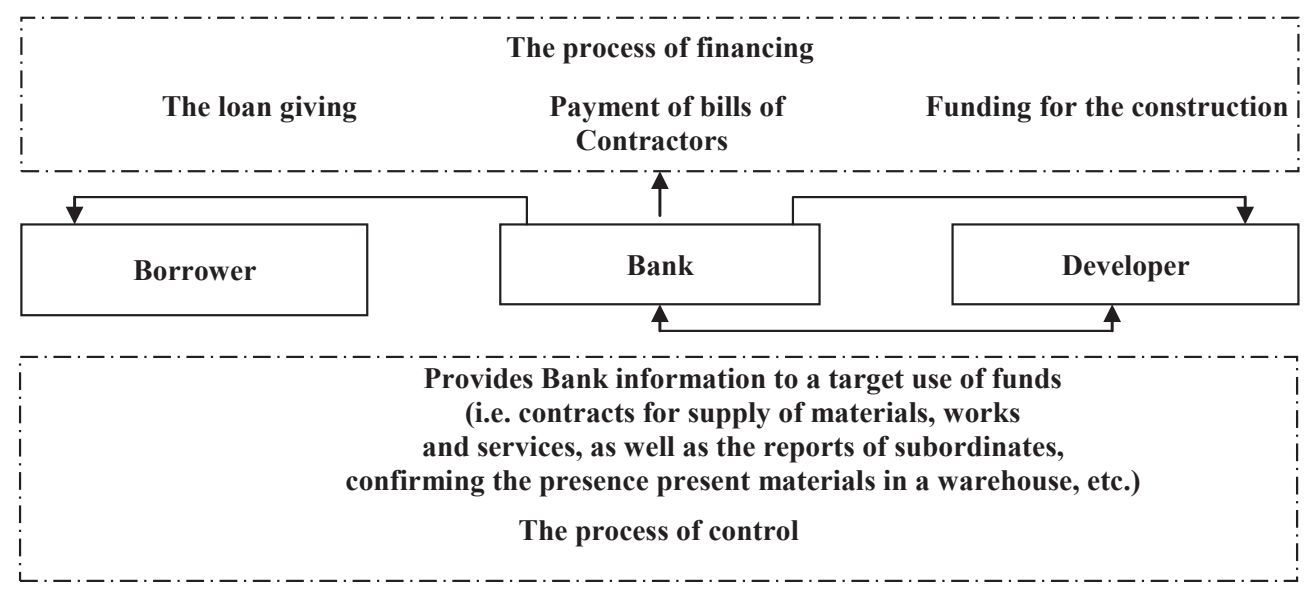

Pic. 1.3. The scheme of financing and control of housing construction

Note. Created by the author 
is manifested in the processes of financing and control (pic. 1.3).

In our opinion, the most rational scheme that we propose, should be the scheme that includes only direct participants of the mortgage market: the borrower as a direct investor housing lender, i.e. the Bank shall credit the applicant for the purchase of housing, and the developer who builds residential facility. The bank acts in a dual role, first is lending to home buyers and secondly in financing of the developer. The Bank is in the process of funding should not only finance, but also to exercise control over the use of financial resources.

Such processes of financing housing construction and control over the use of funds to promote compliance with the construction schedule and minimize level of risk. To ensure an effective mechanism of financing the construction and control functions as for conventional lending, are assigned to the credit division of the bank.

It should be noted that in mortgage lending, which involved not only the borrower and the bank, and the developer and other entities, such as insurance companies, construction and transport companies and other business entities, therefore, to ensure effective and efficient mortgage lending residential real estate banking institutions need to extend the study of the demand for residential real estate and lending, while providing their complexity.

\section{Conclusions}

In our opinion, the study should be considered as a possible infrastructural division of the developer, and possible home buyers. At the same time allocated indicators such as down payment, loan term and interest rate. Note that the initial deposit should be economically justified, based on the cost of the developer, at the stage of the construction and the timetable for construction.

Another positive aspect of mortgage lending can be providing the borrower with some free services, such as: long-term deposit on favorable terms, notary services, insurance, discounts on bank services, providing services to the bank and the developer, given appropriate training of the borrower and so forth.

In addition to the above, it is worth considering the age of the borrower. As practice shows, most need mortgage loans young and wealthy clients. With this purpose, you need also to diversify the types of loans. Young people without significant income, applying for social housing, while the wealthy - for luxury housing and placing home in a prestigious area of the city, and also to a smaller house.

So, on the basis of the study note that in each embodiment, when bank mortgage lending should apply new forms and methods of mortgage lending, as well as implement the latest technology in the field of providing banking services and lending, especially mortgages.

\section{References}

Bazylevych, V. D. (2008). Mortgage market - Kyiv, p. 214-220.

Klimko, G. N. (1997). Basic economic theory: political economy aspect - Knowledge, p. 20; 204-211.

Lagutin, V. D. (2004). The Formation and development of system of mortgage lending. Finance of Ukraine, No. 1, p. $75-82$.

The official website of the State mortgage Agency. [Electronic resource]. - Retrieved from: http:// www.ipoteka.gov.ua

The official website of the Ukrainian National mortgage Association. [Electronic resource]. - Retrieved from: http://www.unia.com

\section{Александр ГОЛОВЕНЬ, Владимир КОРНЕЕВ \\ СОВЕРШЕНСТВОВАНИЕ СИСТЕМЫ ИПОТЕЧНОГО КРЕДИТОВАНИЯ ЖИЛОЙ НЕДВИЖИ- МОСТИ УКРАИНЫ}

Аннотация. Целью работы является совершенствование системы ипотечного кредитования жилой недвижимости в Украине. Ипотечное кредитование появилось в Украине еще в начале XVII века, на сегодня актуальной проблемой является незначительная доля в банковском портфеле долгосрочных ипотечных кредитов, поскольку банки, с одной стороны, стремятся вращать без риска краткосрочные денежные средства, с другой, потенциальный заемщик этих кредитов, к сожалению, не является кредитоспособным. Однако, несмотря на риски, этот банковский продукт является весомым фактором перераспределения и аккумулирования денежных средств, превращение частных сбережений в инвестиционные ресурсы, решение проблемы обеспечения населения жильем, а также способствует стабилизации экономики в стране в целом. Функционирование и распределение ипотечного капитала, возможных финансовых рисков, взаимодействия ипотечного рынка по финансовым, инвестиционным и валютным вопросам, обусловливает определенную сложность механизма функционирования ипотечного рынка Украины в целом. Актуальность данной темы не только в развитии жилищного рынка, но и в целесообразности проведения исследований для развития этого вопроса. Мы представляем анализ институциональной среды ипотечного кредитования жилой недвижимости, которая дала возможность выявить и определить среду современного рынка жилой недвижимости, его 
Vol. 1, No. 2, 2015

взаимосвязь с другими рынками. Методология. В основе данного исследования лежит институциональная структура рынка ипотечного кредитования, которая развивалась независимо от других структур, независимо внутри страны под воздействием конкретных социально-экономических условий и экономической политики. Результаты исследования показали, что следует учитывать как возможности инфраструктурных подразделений застройщика, так и возможности покупателей жилья. При этом выделяем такие показатели, как первоначальный взнос, срок кредитования и процентная ставка. Отметим, что первоначальный взнос должен быть экономически обоснован, исходя из затрат застройщика, на этапе организации строительства и с учетом сроков строительства. Ипотечное кредитование может стать предоставление заемщиком некоторых бесплатных услуг, таких как: долгосрочный депозит на выгодных условиях, нотариальные услуги, страхование, скидки на услуги банка, оказывающих услуги банка и застройщика, учитывая соответствующую подготовку заемщика и так далее. Практическое значение. Как показывает практика, большинство ипотечных кредитов берут молодые и состоятельные клиенты. С этой целью необходимо также диверсифицировать виды кредитов, где молодые люди без значительных доходов, претендующие на социальное жилье, а богатые - на элитное жилье. Значение/оригинальность. На основе этого исследования банки ипотечного кредитования должны применять новые формы и методы ипотечного кредитования, а также внедрять новейшие технологии в сфере предоставления банковских услуг и кредитования, особенно ипотеки не только в Украине, но и в других развивающихся странах. 